\title{
Perancangan Realtime Board Game untuk Melestarikan Alat Musik Tradisional Jawa Tengah dengan Menggunakan Soundtrack dan Mechanics Tile Placement
}

\author{
Septian Yoga Kurniawan ${ }^{*}$, T. Arie Setiawan P. ${ }^{2}$, Jasson Prestiliano ${ }^{3}$ \\ 1,2,3 Program Studi Desain Komunikasi Visual, Fakultas Teknologi Informasi, \\ Universitas Kristen Satya Wacana, Jl. Blotongan, Sidorejo Lor, Salatiga, Jawa Tengah, Indonesia \\ *Penulis korespondensi; Email: wawangabriel@gmail.com
}

\begin{abstract}
Abstrak
Alat musik tradisional adalah sebuah warisan budaya dalam suatu daerah. Namun dengan adanya perkembangan jaman, musik tradisional mulai ditinggalkan oleh masyarakat setempat. Masyarakat lebih suka mendengarkan dan memainkan alat musik modern dibandingkan musik tradisional yang kedepannya bisa menimbulkan kepunahan dari warisan budaya itu sendiri. Salah satu alat musik tradisional yang harus dilestarikan adalah gamelan. Gamelan berasal dari Jawa yang terdiri dari beberapa alat musik yang dimainkan secara bersamaan. Gamelan dimainkan ketika acara adat dan pertunjukan tari tradisional seperti kuda lumping. Maka dari itu dibutuhkan sebuah media untuk melestarikan dan memperkenalkan musik tradisional kepada masyarakat yang belum sadar akan pentingnya menjaga warisan budaya tersebut yaitu Board Game. Board Game dengan Gameplay yang menggunakan Soundtrack untuk mengenalkan gambaran musik gamelan dipilih karena bukan hanya sekedar permainan, namun juga bisa menjadi media edukasi untuk melestarikan alat musik tradisional bagi pemainya. Setelah memainkan permainan ini, pemain lebih tertarik untuk melestarikan kebudayaan daerah dan secara tidak langsung pengetahuan mengenai alat musik tradisonal Jawa Tengah bisa tersebar melalui permainan ini.
\end{abstract}

Kata Kunci: Musik Tradisional, Jawa, Board game, Gamelan, Gameplay, Soundtrack.

\section{Abstract}

Traditional musical instruments are a cultural heritage in an area. But with the changing times, traditional music began to be abandoned by the local community. People prefer to listen and play modern musical instruments than traditional music which in the future could lead to the extinction of the cultural heritage itself. One of the traditional musical instruments that must be preserved is Gamelan. Gamelan comes from Java which consists of several musical instruments that are played simultaneously. Gamelan is played during traditional events and traditional dance performances such as the lumping horse. Therefore, we need a medium to preserve and introduce traditional music to the people who are not aware of the importance of maintaining the cultural heritage, namely a board game. Board games with gameplay that use soundtracks to introduce Gamelan music images are chosen because they are not just games, but can also be an educational medium for preserving traditional musical instruments for the users. After playing this game, players are more interested in preserving regional culture, and indirectly, knowledge of traditional Javanese musical instruments can be spread through this game.

Keywords: Traditional musical, Java, Board game, Gamelan, Gameplay, Soundtrack.

\section{Pendahuluan}

Indonesia memiliki banyak kebudayaan yang dapat dibanggakan, salah satunya yaitu alat musik tradisional. Alat musik merupakan instrument yang dibuat atau dimodifikasi dengan tujuan menghasilkan suara atau bunyi yang membentuk sebuah irama. Setiap daerah memiliki alat musik tradisional. Seiring perkembangan zaman, kepedulian pelestarian kebudayaan nasional khususnya alat musik tradisional menjadi sangat minim. Banyak yang lebih memilih memainkan alat musik modern daripada memainkan alat musik tradisional. Sebagai contoh kurangnya pengenalan dan sosialisai akan budaya Indonesia 
sendiri di masyarakat merupakan salah satu faktor penting mengapa minat masyarakat menjadi kurang terhadap alat musik tradisional.

Pada hasil penelitian yang dilakukan pada mahasiswa UKSW angkatan 2014 - 2018 yang total jumlahnya 30 orang mahasiswa tentang pengetahuan dan minat akan musik tradisional yang terdiri dari fakultas FKIP, FSM, Psikologi, FEB, Pertanian, FTEK, FISKOM, dan FTI bahwa sebanyak 90\% adalah penikmat musik. Namun dari data tersebut hanya $66,67 \%$ yang berminat untuk belajar bermain musik yang terdiri dari $63,33 \%$ berminat untuk bermain musik modern, $6,67 \%$ berminat untuk bermain musik tradisional, dan $30 \%$ berminat bermain keduanya. Alasan yang cukup mendasar dari data diatas adalah karena musik modern lebih mengikuti zaman dan lebih enak untuk didengar, namun dari penikmat musik tradisional itu sendiri berpendapat bahwa musik tradisional memiliki keunikan dan nilai budaya yang kuat di dalamnya. Mahasiswa yang menjadi responden hanya $43,43 \%$ yang mengetahui musik daerahnya.

Menurut bapak Diwoko selaku pengajar alat musik modern keyboard dan drum, peminat musik tradisional lebih sedikit dibanding musik modern, namun bukan berarti kebe-radaan musik tradisional punah. Terbukti dari peminat musik tradisional tembus hingga mancanegara. Alasan bapak Diwoko sebagai pengajar musik modern karena kebutuhan dari pekerjaannya yang salah satunya yaitu pengiring musik Gereja yang membutuhkan kemampuan bermain musik modern. Bapak Diwoko bekerja sebagai pengajar musik modern sejak tahun 2005. Salah satu alasan masyarakat sekarang lebih memilih musik modern karena terbilang praktis, dan keadaan masyarakat sekarang cenderung menyukai hal praktis. Peran masyarakat dan pemerintah setempat dibutuhkan dalam menjaga nilai budaya. Salah satunya yaitu gamelan.

Oleh karena itu, sebuah media diperlukan untuk membantu meningkatkan kesadaran akan pentingnya menjaga kelestarian kebudayaan daerah yang telah diwariskan nenek moyang dan daerah tersebut. Media yang dipilih adalah Board Game, dengan pertimbangan bahwa Borad Game tidak hanya dapat digunakan untuk media permainan tetapi juga media pembelajaran yang menarik.
Tidak hanya belajar sambil bermain, namun Board Game bisa melatih pemainnya untuk bersosialisasi yang bersifat secara langsung bersama-sama dengan pemain lain dalam satu meja dan merasakan keberadaan fisik satu sama lain.

\section{Penelitian Terdahulu}

Penelitian terdahulu yang pertama yang berjudul "Game Edukasi Alat Musik Tradisional di Indonesia Berbasis Android" dapat disimpulkan bahwa upaya pelestarian keanekaragaman alat musik tradisional dalam bentuk game edukasi sebagai media pembelajaran merupakan alternatif diharapkan efektif untuk diterapkan. Game memotivasi pembelajaran melibatkan pemain, sehingga proses pembelajaran lebih menyenangkan. Di sisi lain bahwa bermain game merupakan aktivitas yang tidak asing bagi kalangan generasi muda. Bahkan tidak sedikit bermain game merupakan hobi, sebagaimana hasil survey yang dilakukan 91\% anak usia 2-17 tahun memainkan video game (Granic, et al., 2014). Dengan adanya perancangan board game tersebut diharapkan pemain memperoleh interaksi sosisal yang cukup. Pemilihan tema pelestarian alat musik tradisional diharapkan masyarakat dapat mengenal dan melestarikan warisan budaya yang salah satunya merupakan alat musik tradisional (Rahim, 2016).

Ada pula penelitian yang ditulis oleh Fajarizka dan Rizkiantono yang berjudul Perancangan Board Game Hanacaraka Sebagai Media Bantu Pembelajaran Bahasa Jawa Sekolah Dasar Kelas 3 dan 4. Dapat disimpulkan bahwa hasil riset primer berupa penyebaran kuesioner kepada 100 responden yang berasal dari siswa kelas 3 dan 4 pada beberapa sekolah dasar di Surabaya, didapat hasil bahwa Bahasa Daerah menempati posisi terakhir untuk pilihan mata pelajaran yang disukai. Di samping itu Bahasa Daerah juga menempati posisi pertama untuk mata pelajaran yang paling sulit. Responden menyatakan bahwa materi yang paling sulit pada Bahasa Jawa adalah aksara jawa karena buku atau media belajar yang digunakan kurang menarik. Terkait dengan kasus tersebut, penelitian berlanjut pada tingkat pengetahuan target responden tentang metode pembelajaran yang digunakan. Hasil yang diperoleh adalah 57\% responden tidak tertarik dengan cara pembelajaran yang didapatkan. Sebanyak 58\% responden merasa kesulitan be- 
lajar aksara Jawa dengan menggunakan buku pelajaran dan buku pepak, dan total $55 \%$ kesulitan yang dialami responden saat menggunakan buku pelajaran dan buku pepak adalah penjelasan materi yang sulit dipahami. Oleh karena itu dibutuhkan metode pembelajaran yang dapat membantu mengatasi kesulitan belajar aksara Jawa. Salah satu hal yang paling dekat dengan anak-anak adalah bermain.

\section{Gamelan}

Alat musik tradisional Provinsi Jawa Tengah yaitu gamelan. Seperangkat musik gamelan terdiri dari beberapa instrumen alat musik. Alat musik tersebut meliputi kendang, bonang barung, bonang penerus, saron, slenthem, gender, gambang, kempul, kenong, kethug, sitter, suling, rebab, keprak dan kepyang, bedug, serta gong. Perangkat musik gamelan tersebut terdiri atas dua laras, yaitu laras slendro dan pelog. Satu perangkat musik gamelan laras slendro dan pelog disebut gamelan sepangkon. Selain gamelan, di beberapa wilayah Provinsi Jawa Tengah juga ditemukan jenis alat musik lainnya, seperti rebana, tambur, calung, dan terompet. Alatalat musik ini digunakan untuk mengiringi kesenian khas daerah (Senibudayaku, 2017).

\section{Board Game}

Board game atau disebut juga dengan permainan yang dilakukan di atas papan. Permainan ini dimainkan lebih dari satu orang dalam satu tempat dan papan yang sama. Karena itu para pemain dapat berinteraksi secara langsung dengan pemain lain. Dalam perkembanganya, board game telah berkembang menjadi banyak jenis. Kebanyakan board game mengandalkan strategi, diplomasi, dan keatifitas (Limantara, 2015).

\section{Metode Penelitian}

Metode yang digunakan dalam perancangan board game ini adalah metode deskriptif, yaitu suatu metode yang digunakan untuk menggambarkan atau menganalisis suatu hasil penelitian tetapi tidak digunakan untuk membuat kesimpulan yang lebih luas (Sugiyono, 2005). Strategi yang dipakai menggunakan Linear strategy atau strategi garis lurus. Strategi ini menerapkan urutan yang logis pada tahapan yang sederhana dan relatif sudah dipahami komponennya. Strategi ini sesuai untuk tipe perancangan yang telah berulang kali dilaksanakan. Suatu tahap yang dimulai setelah tahap yang sebelumnya diselesaikan, dan demikian seterusnya (Sarwono, 2007).

Dalam proses pengumpulan data, metode penelitian yang dipakai menggunakan pendekatan kualitatif. Pendekatan ini dilakukan untuk mengetahui fakta-fakta yang ada di lapangan secara mendalam mengenai pengetahuan dan minat akan musik modern dan musik tradisional Jawa Tengah, dimana data akan digunakan tidak hanya sebagai fakta lapangan, tetapi juga untuk membantu proses perancangan. Data yang dikumpulkan, akan menjadi acuan untuk perancangan dan pembuatan board game yang berhubungan dengan pengetahuan akan musik tradisional Jawa.

Analisis data berasal dari sumber tertulis maupun tidak tertulis, dimana sumber tertulis berasal dari segala keterangan dalam bentuk tertulis, dalam hal ini adalah keterangan berisikan penelitian dari seorang ahli yang diterbitkan dari berbagai sumber pustaka, sedangkan sumber tidak tertulis berupa penelitian lebih lanjut mengenai subyek dengan melakukan wawan cara dan penyebaran kuesioner kepada target audience.

Ada empat tahapan yang dilakukan untuk mengembangkan suatu board game menggunakan metode ini. Tahapan-tahapan yang akan dilakukan dapat dilihat pada Gambar 1.

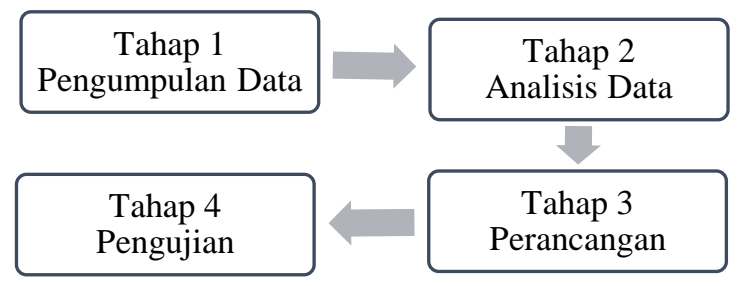

Gambar 1. Tahap Penelitian

Pada tahap pengumpulan data secara kualitatif dengan melakukan wawancara secara langsung dengan narasumber dari pengajar alat musik tradisional maupun modern untuk memberikan sudut pandang mengenai perkembangan alat musik tradisional dan modern. Sedangkan pengumpulan data kualitatif diperoleh dari jawaban kuesioner yang berisikan daftar pertanyaan wawancara yang ditujukan kepada mahasiswa, murid, guru, dan orang tua yang menggunakan jawaban sangat tidak setuju sebagai nilai terendah, cukup setuju untuk nilai tengah dan sangat setuju untuk penilaian tertinggi. Dengan pernyataan mengenai pengetahuan musik gamelan hanya 
diperoleh melalui pelajaran sekolah diperoleh jawaban $83,3 \%$ menjawab setuju. Mahasiswa dan siswa sangat setuju pengetahuan musik gamelan hanya diperoleh ketika pelajaran di sekolah saja.

Hasil analisis data berdasarkan data yang telah dikumpulkan bertujuan untuk acuan menentukan peracangan media yang tepat dan maksimal. Pada tahap perancangan board game ada beberapa tahapan sebelum nantinya mencapai hasil yang dapat dimainkan. Metode perancangan yang digunakan adalah metode prototyping model, dengan metode ini proses menganalisis sistem dapat memperoleh reaksi awal dari para pengguna, sehingga memungkinkan terjadinya perbaikan dan pengembangan yang lebih baik terhadap aplikasi yang akan dibuat. Dari beberapa jenis prototipe, yang akan digunakan sebagai dasar metode penyelesaian masalah adalah prototyping nonoperasional. Prototipe jenis ini merupakan cara untuk memperkenalkan suatu aplikasi baru kepada pengguna (Saputro, 2016). Cara kerja menggunakan prototipe dapat dilihat pada Gambar 2.

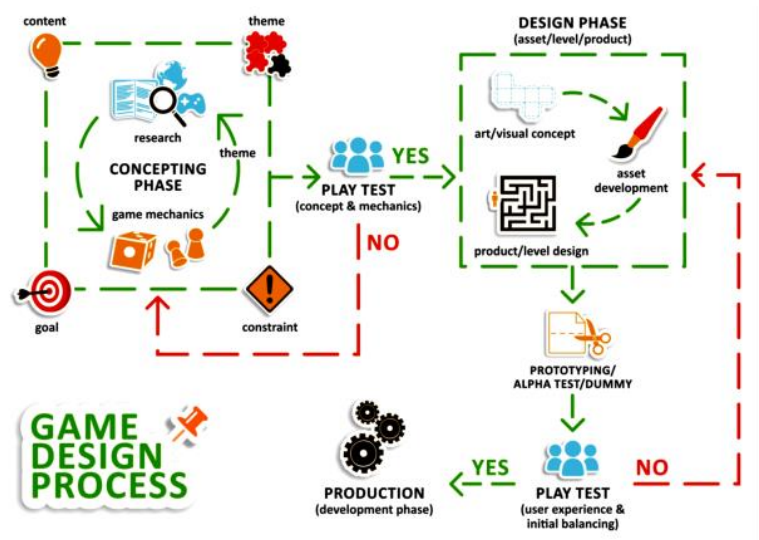

Gambar 2. Game Design Process

Tahap pengujianakan dilakukan pendekatan secara kualitatif dan kuantitatif dengan cara mewawancarai serta memberikan kuesioner untuk meningkatkan efektivitas board game yang dirancang.

\section{Pembahasan}

Diambil dari hasil wawancara yang dilakukan kepada seorang mahasiswa dari luar Jawa mengenai minat dan pengetahuan terhadap alat musik tradisional Jawa, dapat diambil kesimpulan nama alat musik tradisional Jawa tidak begitu dimengerti masyarakat luar Jawa. Sedangkan alat musik modern lebih menarik dan dimengerti karena lebih mudah untuk dimainkan dan mudah untuk dipakai dalam produksi rekaman. Alat musik tradisional Jawa memiliki keunikan dalam bentuk, suara, sejara dan merupakan identitas dari Jawa Tengah dengan ditandai dari bentuk ukiran yang terdapat dibagian badan alat musik daerah Jawa.

Berdasarkan permasalahan tersebut, maka perlu dikembangkan inovasi yang interaktif dan komunikatif, salah satu contohnya menggunakan board game. Fungsi board game tidak hanya sebagai media hiburan, namun juga dapat dimanfaatkan sebagai sarana media pembelajaran yang efektif.

Media Pembelajaran diartikan segala sesuatu yang dapat dipergunakan untuk merangsang pikiran, perasaan, perhatian dan kemampuan atau ketrampilan pebelajar sehingga dapat mendorong terjadinya proses belajar (Arsyad, 2011). Dengan adanya board game berharap dapat memudahkan dalam memahami cara untuk melestarikan alat musik daerah Jawa Tengah dengan dikemas dengan menarik, menyenangkan, dan lebih mudah dipahami, sehingga dapat menumbuhkan minat. Salah satu sisi positif dari board game juga dapat mengajak para pemainnya untuk saling berinteraksi secara langsung. Karena bermain akan lebih seru jika ada interaksi langsung (Manikmaya, 2014).

Proses perancangan board game yang dilakukan ada beberapa fase yang perlu dilakukan. Fase tersebut meliputi:

\section{a. Concepting Phase}

Pada fase ini akan dilakukan pembuatan konsep berdasarkan data-data yang sudah dianalisis dan disederhanakan agar mudah dipahami pemain ketika sedang bermain meliputi tujuan permainan, latar utama permainan, mekanik permainan, aturan permainan, serta alur cerita yang terkandung dalam permainan, kemudian akan dikembangkan dan disempurnakan pada fase berukutnya.

Tujuan utama permainan ini adalah mengumpulkan batu gua yang bisa mengeluarkan suara gamelan dan harus segera keluar sebelum terdengar suara gamelan dari dalam gua. Nama batu-batu tersebut meliputi batu gong, batu kendang, batu saron, dan batu boning. 
Untuk konsep cerita dari perancangan board game bercerita tentang sekelompok orang yang penasaran akan keunikan batu dari sebuah gua di tanah Jawa, batu tersebut bisa mengeluarkan bunyi seperti gamelan Jawa, namun kabarnya jika terdengar suara gamelan, maka orang yang di dalam tidak bisa keluar.

Referensi diambil dari sebuah gua di daerah Pacitan bernama Gua Tabuhan yang batu dari gua tersebut dapat menghasilkan bunyi seperti gamelan. Gua ini mampu mengeluarkan musik karena adanya stalaktit dan stalakmitnya. Stalaktit dan stalakmit yang berukuran besar dan berbeda-beda jika ditabuh akan mengeluarkan bunyi. Bagi yang telah terampil dan mahir bermain musik tabuh akan menghadirkan suara yang berbeda. Bahkan bisa sampai menyerupai suara gamelan Jawa.

\section{b. Design Phase}

Dalam fase ini konsep yang sudah ditentukan akan dilustrasikan dalam bentuk gambar. Pada perancangan board game, memiliki beberapa unsur media yang berbeda. Penggunaan ilustrasi logo juga mempengaruhi pemain agar dapat mengerti tema game tersebut. Logo yang dipilih adalah "Caves Sound", yang artinya adalah suara gua. Alasan pemilihan judul karena untuk memperkuat dari tema yang diambil yang mana suara gamelan yang dihasilkan dari dalam gua. Penggunaan Bahasa Inggris karena diharapkan ke depannya board game ini bisa menarik pemain tidak hanya dalam negeri namun juga luar negeri.

Logo terdiri dari ilustrasi gua menggunakan flat design, dan typografi menggunakan font Hughs, serta ada ilustrasi line art dari bentuk salah satu gamelan yaitu saron yang menopang tulisan "Caves Sound" untuk memperkuat bahwa gua tersebut berasal dari Jawa. Perancangan bentuk dan warna logo bisa dilihat pada Gambar 3.
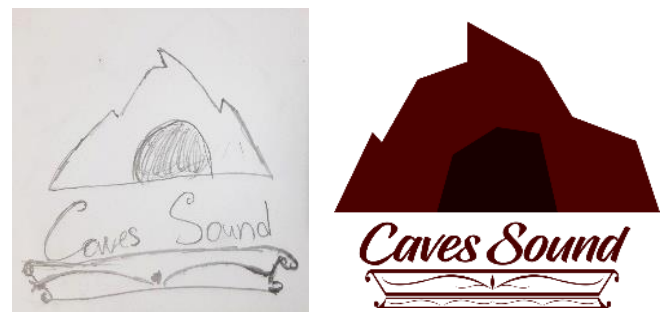

Gambar 3. Perancangan bentuk dan warna logo
Pada fase ini juga dilakukan balancing yang bertujuan untuk menyeimbangkan dalam cara bermain yang mudah dan adil. Setelah dirasa ilustrasi gambar sudah cukup, maka akan dibuat prototipe. Prototipe adalah tahap di mana board gane dapat dikatakan siap dimainkan. Dilakukannya uji coba memainkan prototipe bertujuan untuk melihat sudah baik ilustrasi, ikon, cara bermain, pengalaman permainan secara keseluruhan sebelum nantinya menjadi hasil akhir. Fase ini akan dilakukan berulang kali hingga mendapatkan hasil yang lebih maksimal. Berikut adalah contoh dari prototipe layout komponen sebelum ditambahkan ilustrasi berwarna bisa dilihat pada Gambar 4.

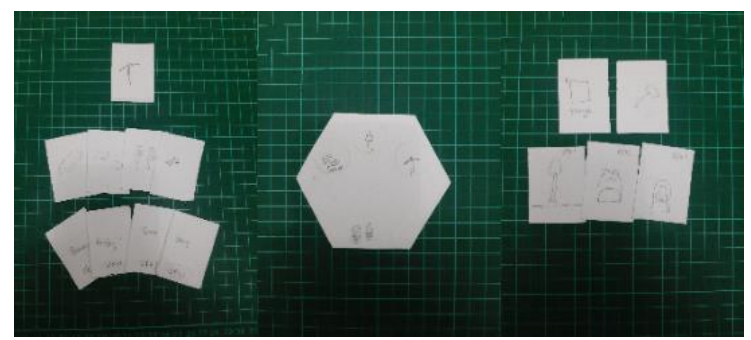

Gambar 4. Prototipe

\section{c. Development Phase}

Prototipe yang sudah baik akan disempurnakan dan dikembangkan. Pengembangan dapat dilakukan pada ilustrasi dan cara bermain board game. Penambahan komponen atau elemen pendukung yang ada tidak akan mengubah cara bermain namun akan menyempurnakanya. Hasil akhir akan dilakukan pada fase ini.

Setelah melalui fase tersebut, maka board game telah selesai dengan judul "Caves Sound". Pemberian nama ini disempurnakan dengan hadirnya sebuah soundtrack gamelan yang akan mendukung cara bermain board game ini.

Dalam board game ini terdiri dari beberapa komponen yaitu tile yang berfungsi sebagai pijakan pion yang menggambarkan suasana di dalam gua yang berbatuan. Tile ini berisikan beberapa gambar ilustrasi tentang sumber daya yang bisa dimanfaatkan pemain untuk membuat peralatan tambahan maupun untuk di simpan. Tile bisa dilihat pada Gambar 5, sedangkan tile bagian belakang bisa dilihat pada Gambar 6. 


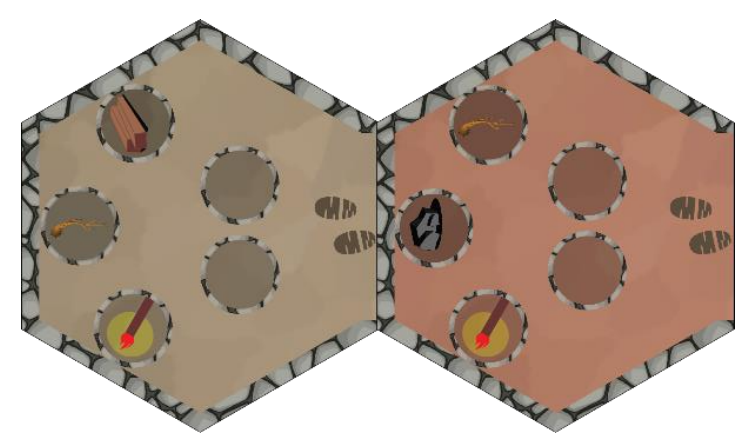

Gambar 5. Tile tampak depan

Tile berbentuk segi enam supaya pemain memiliki ruang gerak yang lebih banyak serta memiliki pilihan untuk menentukan arah peletakan Tile berikutnya. Dengan arah gerak yang lebih dari satu itu memperkuat suasana di dalam gua yang bercabang di dalamnya.

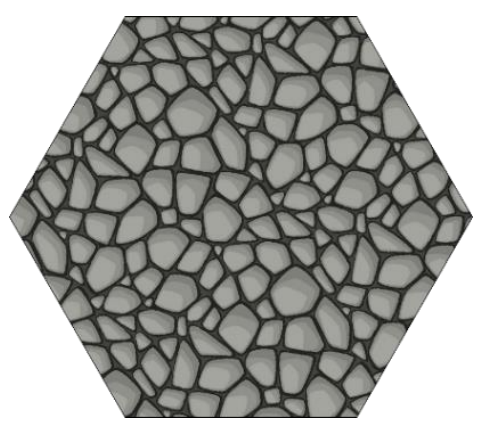

Gambar 6. Tile tampak belakang

Terdapat beberapa jenis token yaitu token akar, batu, batu api, dan bahan bakar. Token tersebut berfungsi sebagai penanda pemain sudah melakukan aksi mengambil sumber daya yang terdapat pada tile atau penanda jumlah sumber daya yang dimiliki pemain. Token bisa dilihat pada Gambar 7.

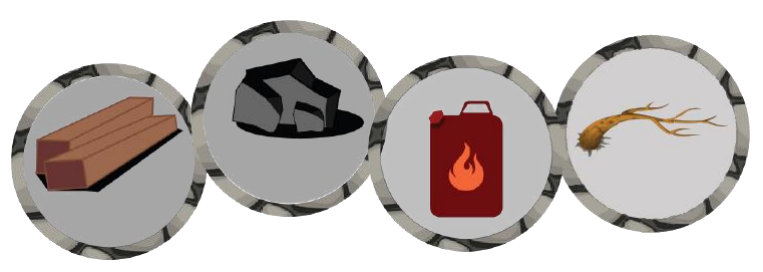

Gambar 7. Token

Terdapat empat buah token pemain untuk melakukan aksi berupa menambang maupun hanya berpindah pijakan. Ilustrasi pion menggambarkan penambang batu. Pembedaan warna bertujuan untuk membedakan pemain satu dengan lainya. Token pemain bisa dilihat pada Gambar 8.

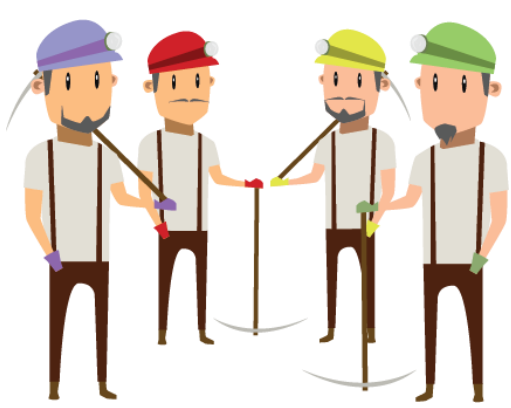

Gambar 8. Token Pemain

Terdapat kartu tambang untuk mengambil sumber daya melalui aksi menambang, dan kartu alat yang berfungsi untuk membentuk suatu alat dan menggunakan syarat dan ketentuan yang terdapat didalam kartu petunjuk pembuatan alat tambahan. Kartu tambang dan alat bagian belakang bisa dilihat pada Gambar 9.

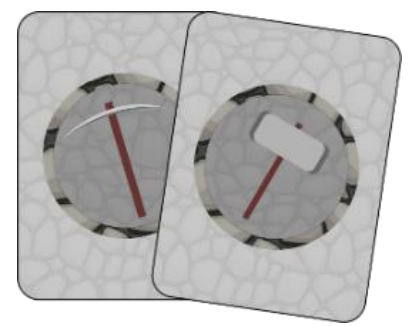

Gambar 9. Bagian Belakang Kartu Tambang dan Kartu Alat

Sumber daya yang bisa didapat ketika menambang bisa dilihat pada Gambar 10.

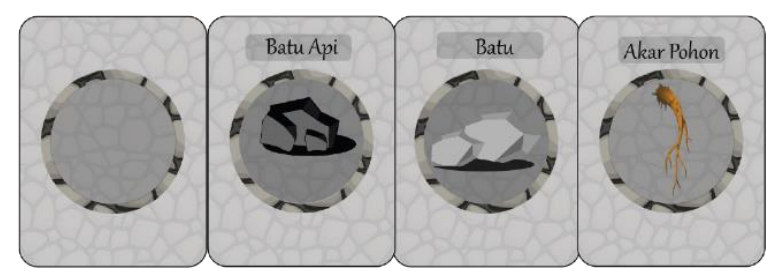

Gambar 10. Hasil tambang

Terdapat tiga kartu alat yang bertujuan untuk membantu pemain dalam permainan. Kartu alat dapat dilihat pada Gambar 11.

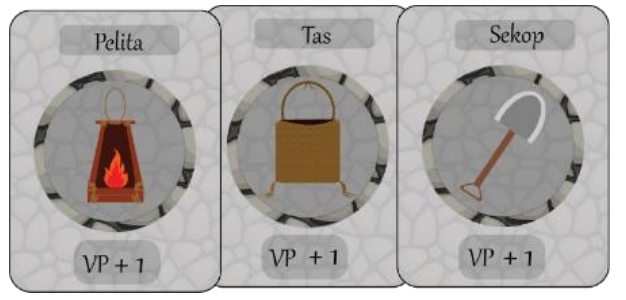

Gambar 11. Kartu alat 
Untuk membuat kartu alat, terdapat petunjuk untuk membuatya. Petunjuk tersebut bisa dilihat pada Gambar 12.

\begin{tabular}{|c|c|}
\hline \multicolumn{2}{|c|}{ Alat Tambahan } \\
\hline$\theta+B+\theta=0$ & $\begin{array}{l}\text { Syarati: unduk mentuthe } \\
\text { tile baru }\end{array}$ \\
\hline 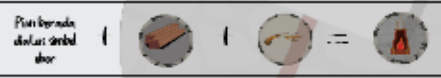 & $\begin{array}{l}\text { Bergeralk } \\
\text { +1 anglah }\end{array}$ \\
\hline$\theta+Q$ & $\begin{array}{c}\text { Menaumbang } \\
+1 \text { kali }\end{array}$ \\
\hline$\theta+\infty$ & $\begin{array}{l}\text { Ruangingentitory } \\
\qquad 1\end{array}$ \\
\hline
\end{tabular}

Gambar 12. Kartu Petunjuk Pembuatan Alat Tambahan

Ada jenis kartu yang harus dikumpulkan pemain yaitu "batu gamelan". Dalam permainan ini, salah satu syarat agar pemain dinyatakan menang adalah mengumpulkan "batu gamelan". Batu tersebut masing-masing bernama batu gong, batu kendang, batu saron, batu bonang. Ilustrasi batu ini berupa $Q R$ code yang bisa diakses dengan cara memindai $Q R$ codemenggunakan handphone yang dilengkapi aplikasi memindai $Q R$ code dan terhubung internet. Ketika memindai $Q R$ code, pemain akan ditujukan ke suatu website yang berisikan gambar gamelan dan suara sesuai nama kartu yang dipindai. Kartu gamelan bisa dilihat pada Gambar 13.

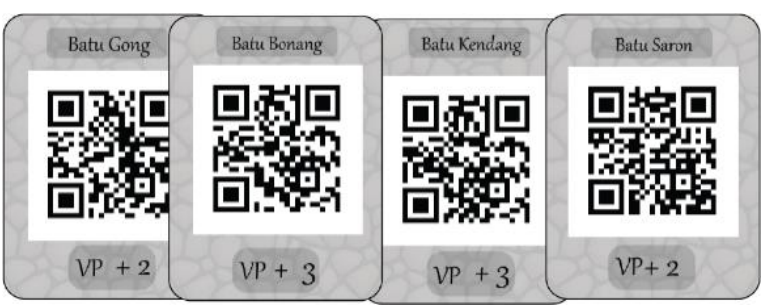

Gambar 13. Kartu gamelan

Dalam board game "Caves Sound" tidak hanya kartu dan papan, namun peran suara juga diperlukan dalam berlangsungnya permainan. Peran suara yang dimaksud adalah adanya soundtrackyang berfungsi sebagai pengatur waktu jika muncul tile berwarna merah. Cara mengaktifkan lagu tersebut bisa dengan memindaiQR code yang tersedia, dan pastikan smartphoneterhubung dengan koneksi internet. Qrcodebisa dilihat pada Gambar 14.

Dalam membuat suatu permainan atau Board Game diperlukan buku panduan atau ruleook. Dalam rulebook berisikan informasi komponen Board Game dan tata cara bermain yang benar.
Ilustrasi rulebook menggunakan latar belakang gambar siluet alatmusik gamelan bisa dilihat pada Gambar 15.

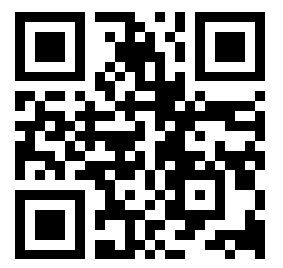

Gambar 14. QR code Soundtrack
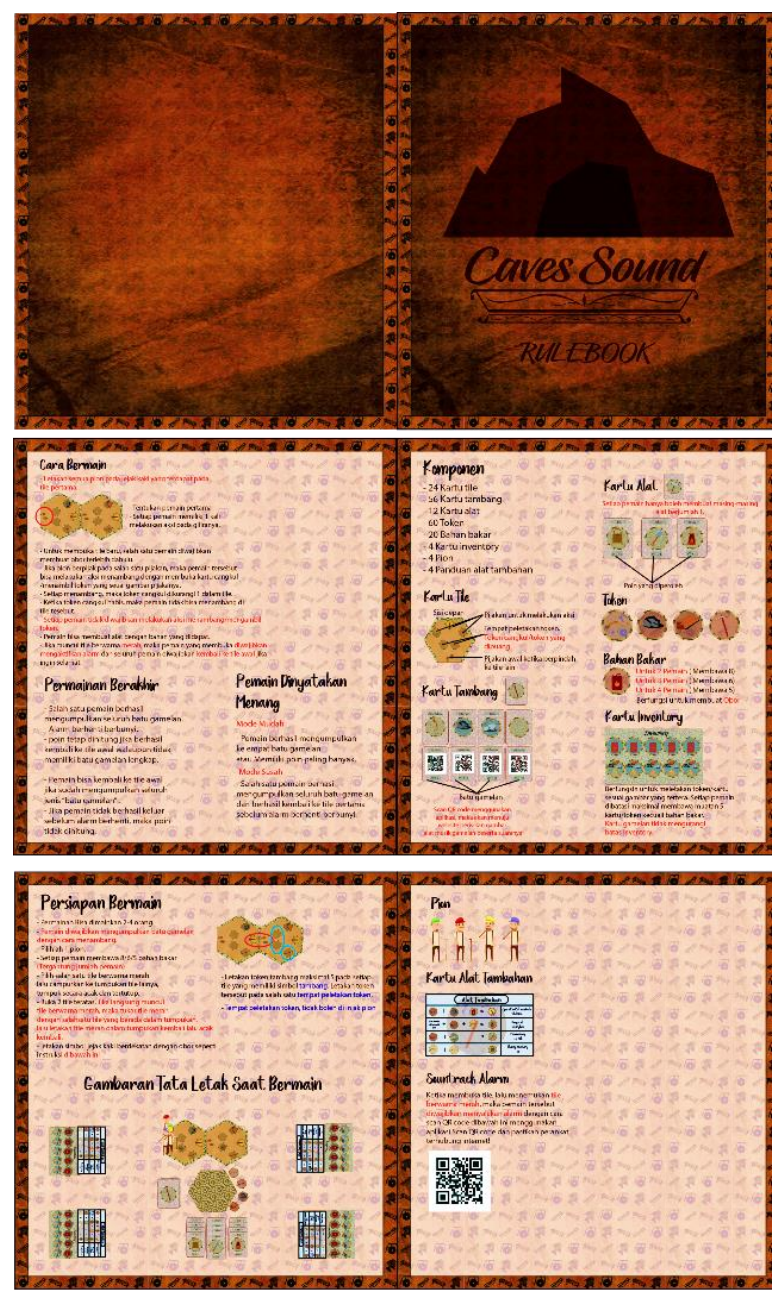

Gambar 15. Rulebook

Kemasan berfungsi untuk melindungi komponen game sehingga selain mudah dibawa, harus memiliki desain yang menarik dan tidak mudah rusak. Semua komponen Board Game dimasukkan ke dalam kemasan. Background kemasan bertekstur seperti keadaan dinding gua yang terkena sinar dari obor. Kemasan atas menampilkan logo dari "Caves Sound" yang terdiri dari ilustrasi gua dan typografi dan ada ilustrasi salah satu gamelan dengan styleline. Kemasan bagian atas bisa dilihat pada Gambar 16. 


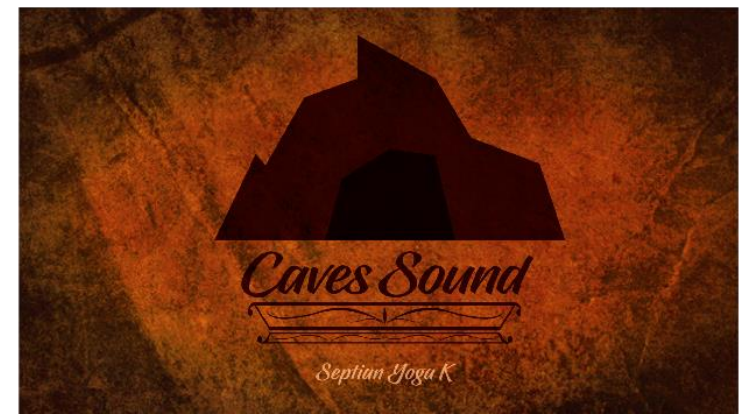

Gambar 16. Kemasan Tampilan Atas

Bagian depan dan belakang hanya menampilkan logo tipografi bertuliskan "Caves Sound". Tampilan kemasan bagian depan dan belakang bisa dilihat pada Gambar 17.

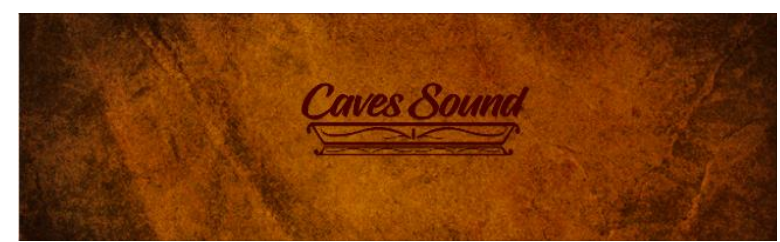

Gambar 17. Kemasan Tampilan Depan dan Belakang

Tampilan kemasan bagian samping kiri berisikan informasi minimal umur, jumlah pemain, dan perkiraan waktu selama bermain board game Caves Sound. Tampilan samping kiri kemasan bisa dilihat pada Gambar 18.

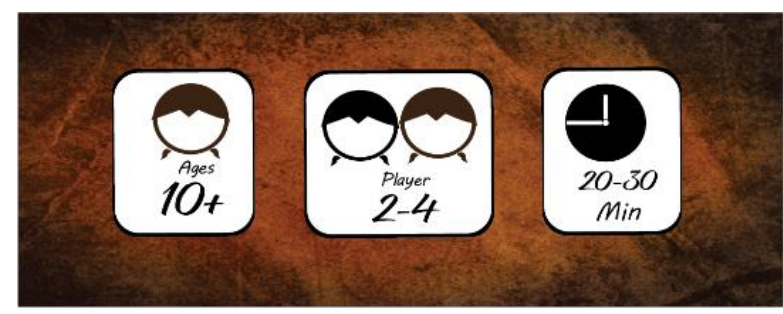

Gambar 18. Kemasan Tampilan Samping Kiri

Kemasan bagian samping kanan berisikan $Q R$ code soundtrack sebagai daya tarik dalam board game ini. Tampilan kemasan bagian kanan bisa dilihat pada Gambar 19.

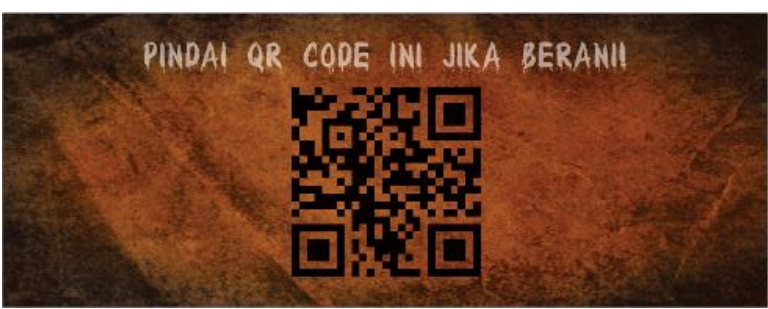

Gambar 19. Kemasan Bagian Kanan
Kemasan bagian bawah berisikan gambaran untuk tata letak saat bermain. Kemasan bagian bawah bisa dilihat pada Gambar 20.

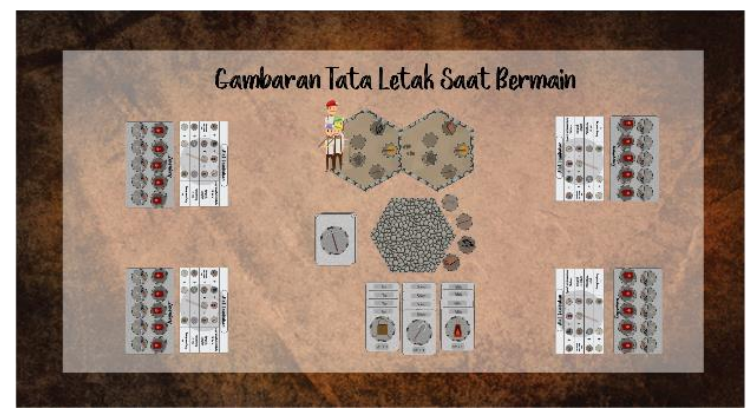

Gambar 20. Kemasan Bagian Bawah

Setelah tahap perancangan selesi, maka tahapan pengujian dilakukan pada ahli, mahasiswa, dan siswa. Pengujian bagian ilustrasi dilakukan pada ibu Birmanti Setia Utami, S.Sn., M.Sn. selaku salah satu dosen pengajar desain grafis "Univesitas Kristen Satyawacana" sebagai ahli desain. Selanjutnya pengujian dilakukan pada ahli board game dari "Hompimpa Games". Hasil pengujian mendapatkan respon cukup baik dalam konsep gameplay dan mekaniknya sudah bagus dan sesuai dengan tujuan dibentuknya media pembelajaran dalam bentuk board game melestarikan alat musik tradisional Jawa Tengah. Pengujian oleh ahli boardgame bisa dilihat pada Gambar 21.

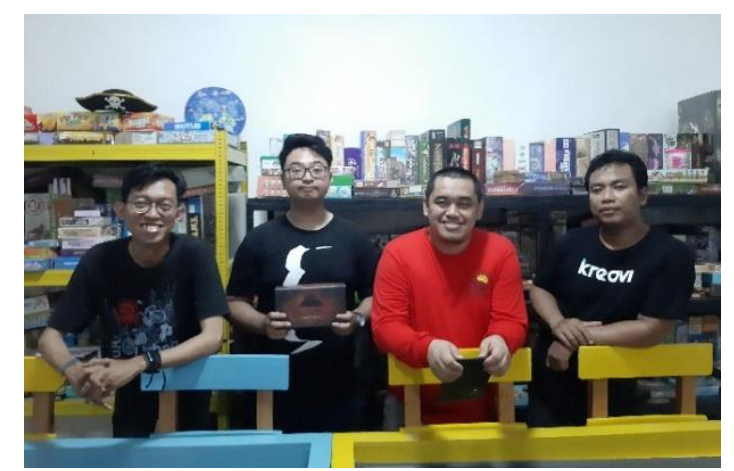

Gambar 21. Pengujian oleh "Hompimpa Games"

Pengujian juga dilakukan pada mahasiswa komunitas board game di Fakultas Teknologi Informasi. Tahap pengujian dilakukan dalam bentuk testplay, di mana pemain berkumpul untuk memainkan board game Caves Sound. Pengujian dilakukan untuk mendapatkan hasil kuantitatif keberhasilan penelitian. Pengujian terhadap mahasiswa bisa dilihat pada Gambar 21 dan Gambar 22. 


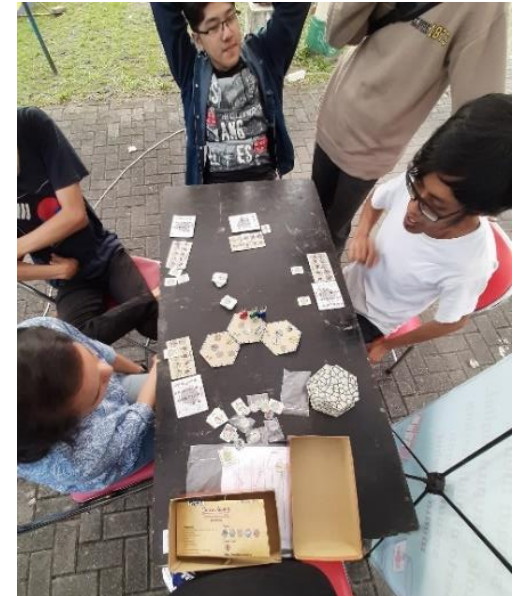

Gambar 22. Pengujian oleh mahasiswa komunitas board game

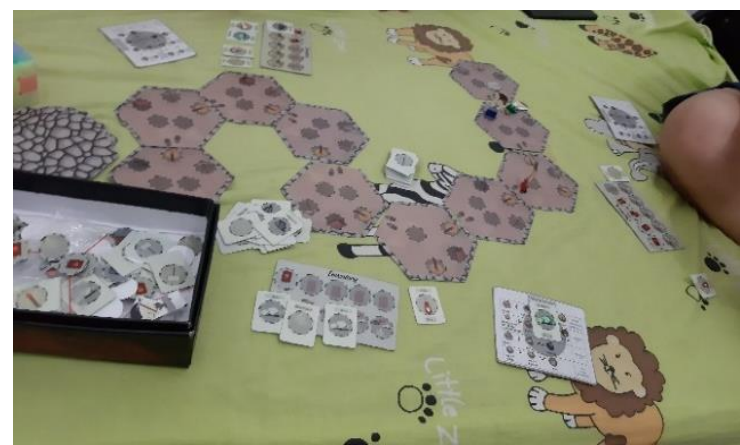

Gambar 23. Pengujian oleh mahasiswa Fakultas Teknologi Informasi

Setelah diuji oleh Tedy, Petter, Narwastu, Albert, Jun, dan Hebert dapat kesimpulan bahwa ide penggunaan musik dalam board game menarik dan dapat digunakan untuk media pembelajaran melestarikan alat musik tradisional Jawa yaitu gamelan.

Pengujian juga dilakukan kepada siswaSD Santa Theresia Marsudirini Salatiga untuk mendapatkan data kuantitatif dengan cara tesplay. Sedangkan untuk hasil kualitatif berdasarkan jawaban dari pertanyaan mengenai respon setelah bermain board game. Hasil dari Pengujian didapatkan persentase $80 \%$ siswa setuju bahwa board game Caves Sound mudah dimainkan kembali. 60\% siswa tertarik terhadap peran musik dalam board game. Namun terdapat $20 \%$ siswa kesulitan dikarenakan keterbatasan waktu dalam kesempatan bermain board game. Dapat disimpulkan pendekatan menggunakan media board game untuk pembelajaran dan menambah wawasan mengenai musik tradisional gamelan berhasil. Pengujian terhadap siswa bisa dilihat pada Gambar 24.

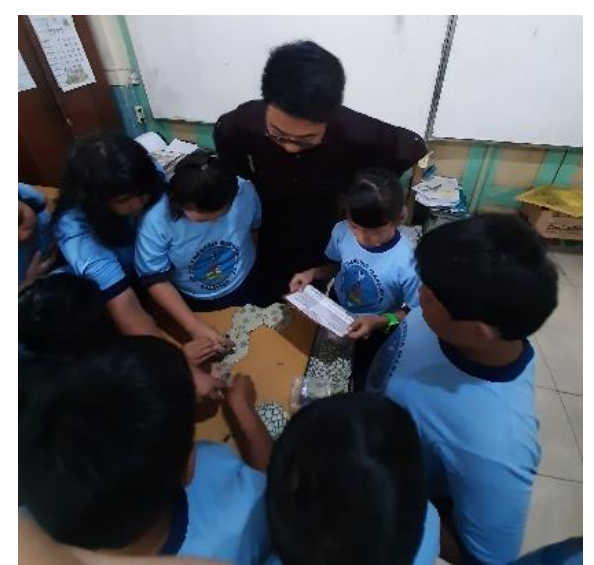

Gambar 24. Pengujian tehadap siswa SD

Melalui hasil pengujian board game Caves Sound berhasil menyampaikan beberapa kesimpulan dan pesan seperti: 1) Mahasiswa dan siswa sekolah mengerti cara mengatur strategi mencapai kemenangan atau keberhasilan ketika bermain board game; 2) Kebudayaan daerah harus tetap dijaga dengan cara memperkenalkan kepada setiap generasi; 3) Indonesia memiliki baeraneka ragam kebudayaan yang sering terlupakan; 4) Mahasiswa dan Siswa dapat mengembangkan hal baru seperti melestarikan kebudayaan daerah melalui board game; 5) Mahasiswa, siswa, dan masyarakat bisa memanfaatkan perkembangan industri board game untuk tetap melestarikan alat musik tradisional yang dimiliki Indonesia.

Melalui hasil pengujian, dapat disimpulkan bahwa alat musik tradisional merupakan warisan budaya yang dapat menjadi ilmu pengetahuan bagi masyarakat daerah maupun luar daerah itu sendiri. Alat musik gamelan dan alat musik daerah lainya layak untuk dilestarikan menggunakan media yang tepat seperti board game.

\section{Simpulan}

Berdasarkan hasil penelitian yang telah dilakukan, dapat diambil beberapa kesimpulan. Masyarakat yang tidak mengetahui adanya alat musik tradisional bernama gamelan menjadi mengerti ketika bermain board game Caves Sound karena terbantu oleh ilustrasi gambar dan suara musik yang terdapat di dalamnya, serta pengenalan latar tempat dalam board game Caves Sound yang berdasarkan gua di Pacitan Jawa Timur yaitu Gua Tabuh. 


\section{Daftar Pustaka}

Arsyad, A. 2011, Media Pembelajaran, Retrieved from

https://s3.amazonaws.com/academia.edu.docu ments/31182216/jiptiain--umarhadini8584-5baii.pdf?AWSAccessKeyId=AKIAIWOWY YGZ2Y53UL3A\&Expires $=1531219666 \&$ Si gnature $=$ snJlnkd\%2BA4fdRoyFipTK8xif9 tE\%3D\&response-contentdisposition=inline $\% 3 \mathrm{~B} \% 20$ filename $\% 3 \mathrm{DM}$ edia_pembe.

Granic, I., Lobel, A., \& Rutger. 2014, The Benefits of Playing Video Game, American Psychologist, 66.

Limantara, D. 2015, Perancangan Board Game Untuk Menumbuhkan Nilai-Nilai Moral Pada Remaja, Program Studi Desain Komunikasi Visual, Fakultas Seni dan Desain Universitas Kristen Petra, 3.

Manikmaya. 2014, Interaksi Langsung Dalam Bermain Itu Penting, Retrieved from http://manikmaya.com/interaksilangsung-dalam-bermain-itu-penting/.
Nugroho, E. 2013, Game Design Process. Retrieved from www.slideshare.net/kummara/gamedesign-process-2013-kummara.

Rahim, F. 2016, Game Edukasi Pengenalan Alat Musik Tradisional di Indonesia Berbasis Android, 1-2.

Saputro, D. 2016, Perancangan Media Edukasi Kandungan Berbahaya Junk Food bagi Anak Sekolah Dasar Menggunakan Teknologi Augmented Reality Berbasis Android. Skripsi Universitas Kristen Satya Wacana.

Sarwono, J, 2007, Strategi Penelitian, Graha Ilmu.

Senibudayaku, 2017, Mengenal Kebudayaan Daerah Jawa Tengah,

Retrieved from senibudayaku https://www.senibudayaku.com

Sugiyono. 2005, Definisi Metode Deskriptif, Retrieved from https://idtesis.com/metodedeskriptif/ 